\title{
3D SURVEY OF THE EARLY-MIDDLE BRONZE AGE WORKSHOP COMPLEX AND CEMETERY AREA AT ERIMI-LAONIN TOU PORAKOU (CYPRUS)
}

\author{
G. Tucci $^{\text {a, }}{ }^{*}$, L. Bombardieri $^{\text {b }}$, A. Conti ${ }^{\text {a }}$, L. Fiorini ${ }^{\text {a }}$ \\ ${ }^{a}$ GeCo - Geomatics and Communication for Cultural Heritage Laboratory, Univ. of Florence - grazia.tucci@unifi.it \\ ${ }^{\mathrm{b}}$ KVP - Missione archeologica italiana a Erimi, Dipartimento di Scienze dell'Antichità, Univ. of Florence - \\ luca.bombardieri@unifi.it
}

KEY WORDS: Archaeology, Cultural Heritage, CAD, Representation, Modelling, Laser Scanning

\begin{abstract}
:
Kouris Valley Project is an archaeological research project held from 2007 by University of Florence and directed by Prof. A. M. Jasink, under the field direction of Dr. L. Bombardieri in the Kourion area (Limassol, Cyprus). During the 2010 field season the collaboration of GeCo (Geomatics and Communication for Cultural Heritage Laboratory, University of Florence) was requested with the aim at the laser scanner survey of Erimi-Laonin tou Porakou site area. The survey involved two areas, a workshop and a cemetery, as well as some small ceramic finds. Range maps was used for different aims: to make a full-scale replica of a tomb to exhibit at Limassol museum and for the documentation of the excavation of the workshop. This one is a rather extreme case study: most significant artifacts are shallow carvings into bedrock and could be confused with natural elements. In this case the aim was to get automatic and accurate drawings comparable with traditional ones. The paper reviews the expressive potential of drawings done using different techniques and softwares, each one with its assets and restrictions.
\end{abstract}

\section{AIMS AND EXPECTED NEW DATA}

The general aim of this research project is to cross-check the application of new dedicated survey techniques to the analysis of the archaeological evidence from the site of Erimi-Laonin tou Porakou (Limassol, Cyprus).

The topographic peculiarities of the site area and characteristic building techniques of domestic and funerary architecture as well as the necessity of a proper layout in the graphic representation hinted as a whole at trying out different approaches.

This preliminary study, as a joint team collaboration of archaeologists and architects from the University of Florence (from GeCo and the Missione Archeologica italiana ad ErimiKVP), can provide interesting new data both from methodological and archaeological perspective.

Thus, we can expect from the analysis of this specific casestudy to outline a preliminary picture of the main problematic aspects to be solved in performing an exhaustive data capture and in planning a quick data processing system to produce significant graphic representation of similar archaeological evidences.

In this project 3-D survey methods was especially devoted to fulfill archaeologists' requests about:

- drawings that could render the complicated site morphology and comparable with traditional ones;

a project of a full-scale replica on a part of the excavation area for museological purposes;

digital models of small finds for documentation and communication.

Therefore, a general study of the intra-site topographic peculiarities and building techniques adopted from context to context can broaden the analysis of use and function of the different areas at Erimi-Laonin tou Porakou. Hence, the development trends during the Bronze Age (Early Cypriote to Late Cypriote I) can be actually better outlined and, in a wider perspective, the role of the site within Kourion region. A new trend of interest for the Kourion hinterland in the Bronze Age can be evidenced in the last years. Two matching aspects have possibly played a peculiar role in the re-evaluation of the region history within the southern Cyprus regional horizon before the development of the Greek and Roman city of Kourion:

- on a wider scale, the general increasing of regional studies dedicated to ancient landscape in Cyprus and the specific definition of theoretical models for the analysis of control and use of the territory by the cities entities in the pre-classical Cypriote society, in particular the relevant interpretative model elaborated by Maria Iacovou for the Late Bronze and Iron Age periods (Iacovou 2007; 2008).

- $\quad$ on a regional scale, the development of surveys and excavations projects in the area. As to these ones, a raising activity can be recorded as to the survey works by Stuart Swiny as well as to the new excavations on the site of Episkopi-Bampoula by the University of Cincinnati (Swiny 1981; 2004; Swiny, Mavromatis 2000; Walberg 2001-2009) and by the excavations carried out by the Department of Antiquities of Cyprus in Alassa and Erimi (Hadjisavvas 1996; Flourentzos 1991, 2010).

The overall picture hinted to plan a preliminary survey during the 2010 field season and to carry out this research study dedicated to the archaeological evidence of Erimi-Laonin tou Porakou.

\section{THE SITE}

\subsection{Erimi-Laonin tou Porakou}

The site area of Erimi-Laonin tou Porakou has been surveyed and systematically excavated from 2007 as a research project of

\footnotetext{
* Corresponding author.
} 
the University of Florence, in collaboration with the Department of Antiquities of Cyprus.

The site area of Erimi-Laonin tou Porakou lies on an high plateau on the eastern river slope facing southward the Kouris Dam, just on the border between the Ypsonas and Erimi villages (Cadastral Sheet LIII/ 46, Plots 331-336, 384; geocoordinates $34^{\circ} 42^{\prime} 43.00^{\prime \prime} \mathrm{N}, 32^{\circ} 55^{\prime} 23.00^{\prime}$ "E). Erimi-Laonin tou Porakou was first identified in 2007 as a result of a survey project focusing on the middle and lower Kouris Valley with the aim of outlining the general patterns of landscape use and the sequence of the ancient occupation in the valley area (Bombardieri and Jasink 2010; Bombardieri et al. 2009; Bombardieri 2010). The preliminary evidence paved the way towards further investigations in the site area, aiming at better clarifying the sequence of occupation and possibly to understand the function and use of the different areas of the site. The focus was on the use of differently oriented investigation methods on site. The 2008-2010 seasons dealt with a series of different topographical and geophysical prospecting (such as the magnetometry of specific areas), an intensive survey collection of diagnostic materials, and excavation on the site area (Menozzi et al. 2010; Bombardieri 2009).

\subsection{Chronology and contexts}

The general chronology of the settlement sequence within the site area, as recorded by survey collections and excavation results on the top mound (Area A), first lower terrace (Area B), and southern cemetery area (Area E), hints at occupation throughout two main periods (Periods 1 and 2). At this point the most attested to is the earlier Period 2, ranging from the Early Cypriote to the Late Cypriote I periods (EC II/III-LC IA), with two phases attested to within the sequence (Period 2: Phases A and B); the following period (Period 1), apparently following a lengthy hiatus, is related to a possible re-settlement during the late-Hellenistic and Roman periods.

As far as our discussion is concerned, two excavated contexts are of relevance: the top mound workshop complex (Area A) and the southern cemetery (Area E).

2.2.1 The workshop complex: The workshop complex cleared on the top mound Area A extends over an area of 20x15 $\mathrm{m}$, which is currently being investigated (Bombardieri, forthcoming). This complex highlights the organization of distinctive spaces. The natural limestone top mound bedrock has been carefully worked in order to construct a combined system of deep basins carved at different depths, connected to each other by a series of flow channels.

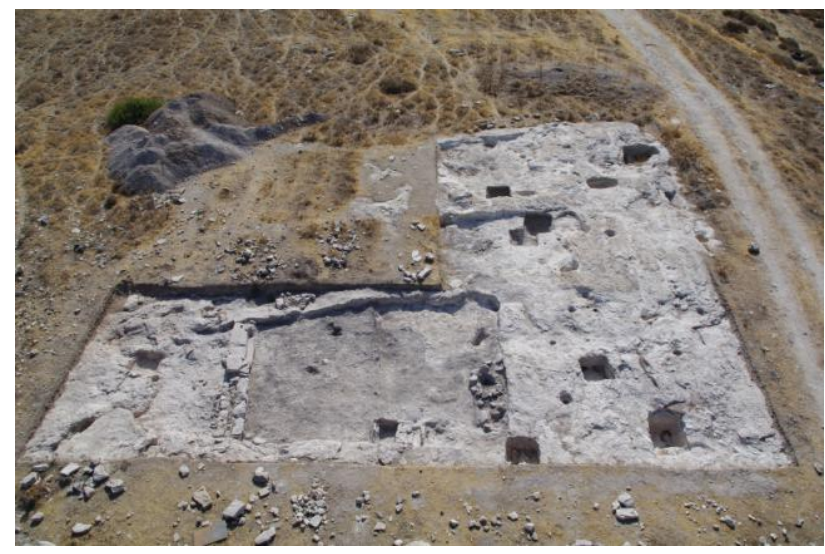

Figure 1. The workshop area
Thus the features of the working and storing devices, which find few counterparts in the Kourion region (and particularly in Erimi-Kafkalla), point to a Workshop Complex devoted to activities organized and processed following certain steps, each of them possibly to be performed in distinct working areas and flanked by a storage area aimed at collecting and preserving raw materials, processed materials and/or final products. The recent results of macro-characterization analyses on filling soil sampled from the storage pithoi in Room 1, carried out at ArcheoLabio, Centro di Ricerche di Bioarcheologia, University of Bologna, revealed interesting data to hypothesize a functional interpretation for the Workshop Complex. The samples do not contain any trace of cultivated plants remains, nor olives, wheat, or barley, but only wild plants, with a significant presence of species (Rubiaceae like the Galium) usually also employed for dyeing (Carra 2010). This evidence and these results are preliminary and await further confirmations, but in any case, at this stage, a possible use of the area for textiles or leather dyeing activities can be suggested.

2.2.2 The southern cemetery: The EC-MC cemetery area (Area E) extends along a series of two terraces sloping from the top mound towards the southeast. The investigation within the cemetery Area E has aimed at outlining the relationship with the sequence of phases evidenced in the top mound Workshop Complex and thus clarifying the general chronology of the occupation of the site, during the EC-LC I period.

A series of seven rock-cut tombs (Tombs 228-232; 240-241) were excavated during the 2008-2010 field seasons. As far as the typology is concerned, all the tombs show single, small, irregularly rounded chambers with a cave-like section. A short dromos leads to the grave chamber of tombs 228-230, located on the upper terrace, where the stomion was roughly outlined by regularizing the terrace facade. On the contrary, tombs 231, 232, 240 and 241, found unlooted and located on a lower terrace just flanking the modern road going from Erimi to the small village of Vounaros, even if showing the same basic plan, have no dromos and highlight a wider dimensional variability. The offering goods deposits display a wide repertoire of ceramics and small objects. The small finds and ceramic assemblages, with regards to their typology and decoration patterns, point to a standard South Coast production, mainly ranging from EC II/III to MC III/LC IA period, thus drawing a sequence of use contemporary with the stratigraphic deposits evidenced on the top mound Workshop Complex (Area A). As to the pottery assemblage from the Area E cemetery tombs, a wide repertoire of standard Red-Polished, Drab-Polished and

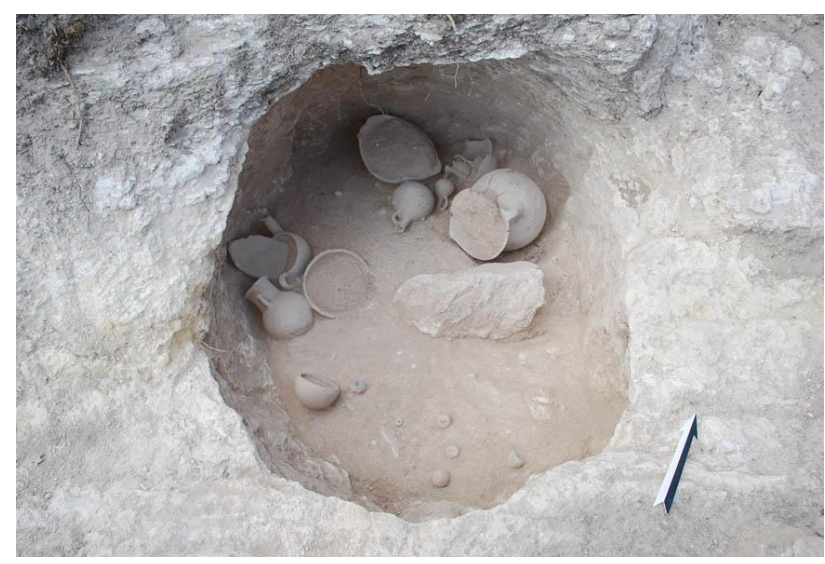

Figure 2. The tomb 231 with its offering deposit 
Black-Slip wares vessels have been found. Moreover, it is particularly meaningful the presence within the offering deposit of few vessels which can be referred to an incised decoration pattern typical of the South Coast pottery production. The variation, already identified by Paul Åstrom (Type VIIIB, 6e), and by the American archaeologists in Episkopi-Phaneromeni defined as Red Polished Punctured ware or differently Episkopi ware (Åstrom 1972: 95; Carpenter 1981: 61-64; Herscher 1976, 1991; Swiny 1981: 57-58), can be dated back to the Late Middle to the beginning of the Late Bronze Age period (Late Cypriote IA).

The focus analysis of the offering-goods repertoire from each tomb can reveal further interesting data about the chronological range of use of the cemetery area.

\section{SURVEYING ARCHAEOLOGY}

\subsection{A survey for the archaeologists}

At present time, laser scanner survey is widely diffused in archaeology. That technology, performing a systematic measure of 3-D coordinates, allows a geometrically accurate survey of highly uneven sites or very deteriorated objects (e.g. Bonora et al. 2006, 2008, Remondino et al. 2008). Furthermore, its speed allows to update the survey during excavation progress and help to study the site stratigraphy (e.g. Sibilano 2008).

Digital data can be useful for the "Users", specialists on knowledge and conservation of Cultural Heritage -in this case the archaeologists- if the "Providers", specialists on 3-D surveying, are even able to produce documents comparable with traditional 2-D drawings and that "Users" can look through and use according to the usual ways of their field.

Furthermore, 3-D models are really effective for communication and dissemination, but hardware and/or software restrictions can force to oversimplify them according to requirements more related with computer graphics than with archaeology (Laurenza 2008).

About Workshop Complex, as example, a basic request was to get a survey of the excavation site comparable with 2-D drawings done during previous field seasons. In the Workshop site, the main elements are mostly artifacts lying above the ground or cut underneath the natural ground level. This condition entails an predominantly 2-dimensional overall morphology, with shallow carvings, elaborate slopes systems and sudden variations of the third dimension in small cavities. In such a context, the study of the surface requests a more accurate detail than the one got during previous field seasons done with traditional survey techniques. So it was necessary to get an high level of detail on a rather broad area. Moreover, excavation area has few easily identifiable man-made elements (as walls), and many others that can get confused with the natural bedrock.

Traditional survey techniques, because of their discrete nature, maximize the specialists' competences to summarize useful data directly on the field (Medri 2003, Marchetti 2008). Laser scanner survey, despite excellent metric performances, produces undifferentiated primary data sets that are not inherently useful for archaeologists (e.g. Yamaguchi 2010).

So surveyors and archaeologists have to work together to find most effective ways to get a posteriori useful data and to display them according with archaeological drawing codified rules too.

\subsection{A survey for communication}

About the Tomb survey, there was opposite needs. In this case it was examined the chance to show the research results designing for the Limassol Archaeological Museum a full-scale replica of Tomb 231 to display into it the original offering deposit as it was found. Furthermore, archaeologists asked to make some virtual 3-D models of some ceramic finds according to the guidelines set within the MUS.INT. project "An interactive museum system design: The virtual museum of the Aegean and Cypriot antiquities collections in Tuscany", directed by Prof. A. M. Jasink (Tucci et al. 2010).

These are surveys mostly oriented on communication for products addressed to a wide and non-specialized audience, wherein metric accuracy joins visual quality.

\section{DATA ACQUISITION}

Data acquisition on field required one day with a Leica Geosystems HDS 6000 scanner. Most challenging task was to report all cavities avoiding no data zones, so it was necessary to do many scans even in relatively small areas. About Workshop, as most elements are ground level, it was necessary to do many close scans as each one could map only a small area around the device with the requested point density. In the Tomb survey, on the other hand, the task was to position the scanner to get al useful data in and around a small cave.

In both cases, targets was placed for the roto-translation of the range maps in the same coordinate system.

Ceramic finds was scanned by a NextEngine's triangulationbased laser scanner according with the above mentioned MUSINT guidelines.

\begin{tabular}{|l|c|}
\hline Surveyors & 3 \\
\hline Acquisition time (days) & 1 \\
\hline Laser scanner & Leica Geosystems HDS 6000 \\
\hline \multicolumn{2}{|c|}{ Workshop } \\
\hline Survey area & $240 \mathrm{mq}$ \\
\hline Laser scanner stations & 22 \\
\hline Acquired targets & 12 \\
\hline Acquired spatial coordinates & 89.745 .349 \\
\hline \multicolumn{2}{|c|}{ Cemetery } \\
\hline Survey area & $28 \mathrm{mq}$ \\
\hline Laser scanner stations & 4 \\
\hline Acquired targets & 5 \\
\hline Acquired spatial coordinates & 19.532 .428 \\
\hline
\end{tabular}

Table 1. Summary of the acquired range data

\section{DATA PROCESSING AND VISUALIZATION}

\subsection{The Workshop}

The problem to get 2-D drawings from range maps, possibly using automatic techniques, is widely discussed. During this project we reviewed the expressive potential of drawings done with different techniques and softwares, each one with its assets and restrictions:

$$
\begin{aligned}
& \text { point clouds (using Leica Geosystems Cyclone) } \\
& \text { mesh shaded or texturizated (using Geomagic Studio) } \\
& \text { vectorization (using Bentley Systems Microstation). }
\end{aligned}
$$

5.1.1 Point clouds: Point clouds became almost a paradigm of laser scanner survey and they are often straight used for rendering because of their similarity with the stippled drawing 
technique (e.g. Jiménez Hernández 2010). On the other side there are some important limitation to their use:

Point clouds are transparent, so objects with front and back sides request some manual editing;

Shading results from gathering of points where the third dimension suddenly changes, otherwise the image is sometimes poor of detail;

An efficient editing of point clouds requests dedicated software packages.

CAD software allow to import only a small amount of point as graphic primitives, usually enough for vectorization but not sufficient for final drawings. For instance, the configuration we used allowed to import about 1 million of points, while the Workshop Complex, once cleaned, counts more than 20 millions of points.

On the other side, new CAD packages trend is to let show large point clouds as referenced files, directly or using dedicated plug-ins. Last Microstation edition (V8i SELECTSeries 2) has a built-in Pointools engine and includes some editing tools as clip, filter, colorize according to many criteria (for example, for elevation). Anyway, data editing still results inadequate for many needs and, most of all, it's difficult to print point clouds or to save raster images with a good visual quality, mostly to publish small scale drawings.

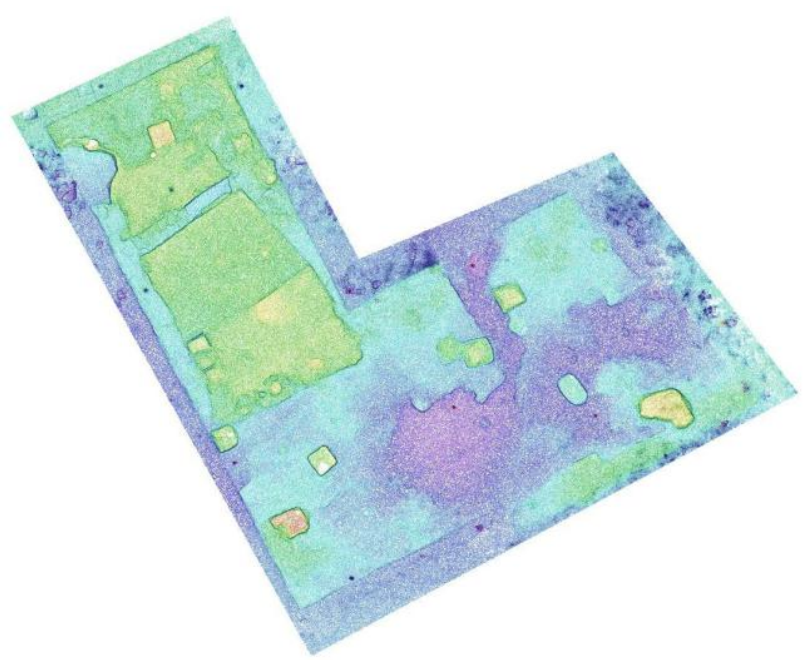

Figure 3. Overall plan of the workshop as a point cloud colorized by elevation using Microstation

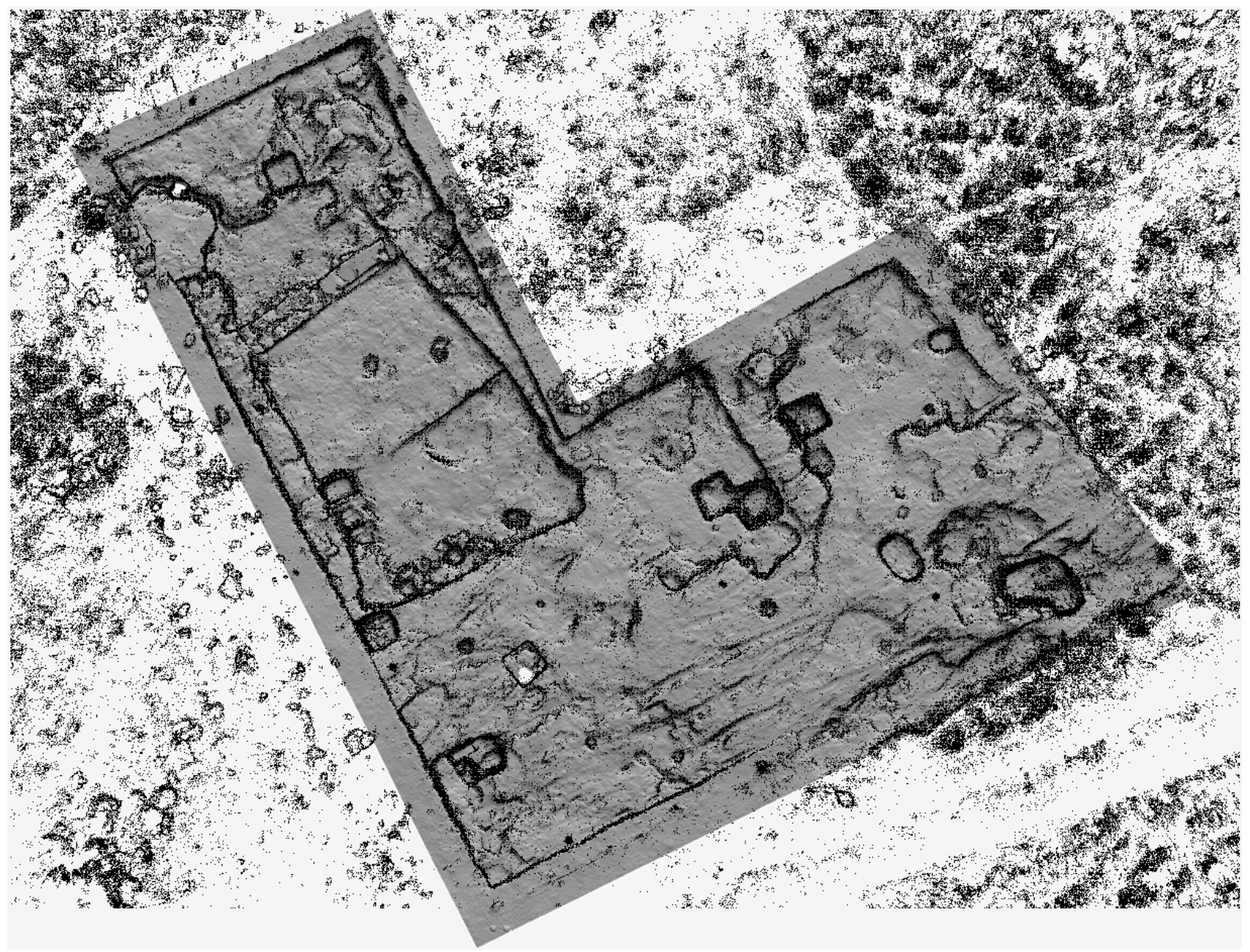

Figure 4. The same plan as a superimposition of the point cloud on a shaded mesh 


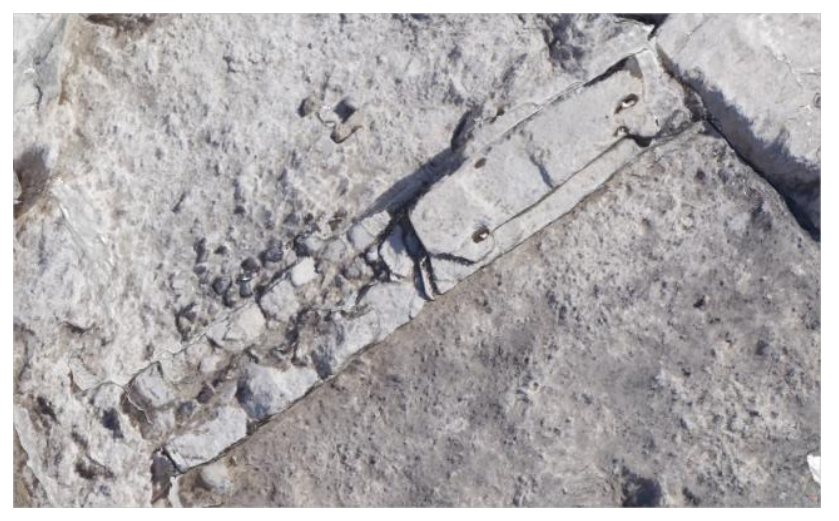

Figure 5. Detail of the workshop plan: mesh with photographic texture

5.1.2 Meshes: Using shaded meshes overcomes the problems of transparency and shading (as lighting can be adjusted on 3-D model). On the other hand, to create a good mesh is a time-consuming task and hardware and/or software restrictions could compel drastic reductions of original data. Again, as like as using point clouds, the scan resolution affects the quality of details, while it's difficult to keep the best resolution on large areas. A solution could be to superimpose the point cloud on the mesh, as the shading helps visibility in almost flat areas and point cloud enhances features (Figure 4). Another way is to apply a photographic texture on meshes to get orthophoto-like pics with a good geometry, adjustable lighting and best detail quality (Figure 5). Nevertheless, orthophotos have same disadvantages than photographs versus drawings: the lack of difference between important and incidental elements. For instance, in our study it's sometimes difficult to distinguish man-made elements from natural ones because they both have the same radiometric features and similar shape.

5.1.3 Vectorization: A more or less automatic vectorization from range maps is a widely diffused (and time-consuming) technique to get line drawings. Often literature doesn't emphasize that step in data processing, maybe because

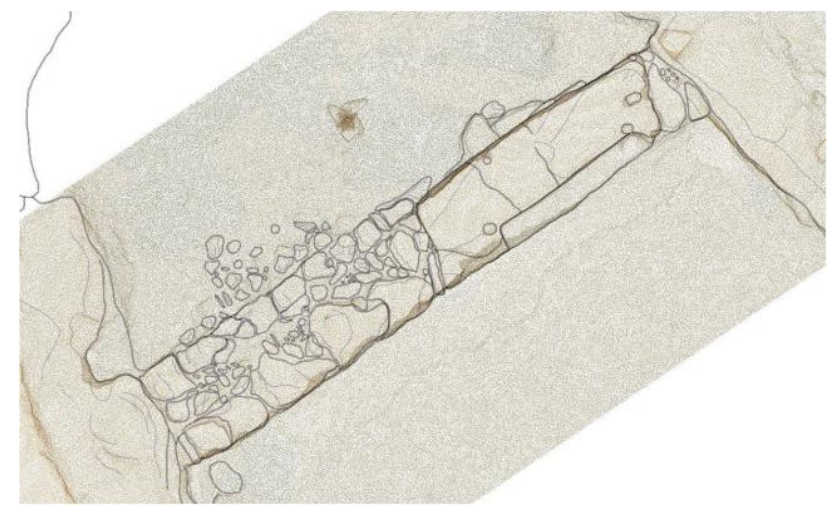

Figure 6. Detail of the workshop plan: vectorization on point cloud

vectorization seems a rather empirical task that not requires further explanations. In this project vectorization is used to improve the above mentioned techniques, locating on point clouds the features identified by archaeologists on excavation sketches. As the survey object was unsuitable for an automatic feature extraction, a manual vectorization was necessary. Even if this step requires about the same time than a traditional manual drawing, results are much better because features, already selected by archaeologists' competence and sensitivity, are placed with best geometrical accuracy. Drawing on a phototexturized mesh is really easier to distinguish relevant objects from secondary ones, and it's more independent by draftsman skill than traditional drawing (Figure 8).

\subsection{The tomb 231}

Range maps nevertheless allow kinds of representations more difficult to get in traditional ways (e. g. Costantino 2009). Tomb 231 is considered the most meaningful in the area because of its typology and its unlooted offering deposit. The opportunity to show the original ceramics and small objects in a full-size replica of the tomb at the Limassol museum, drove to find the best way to reproduce the tomb.

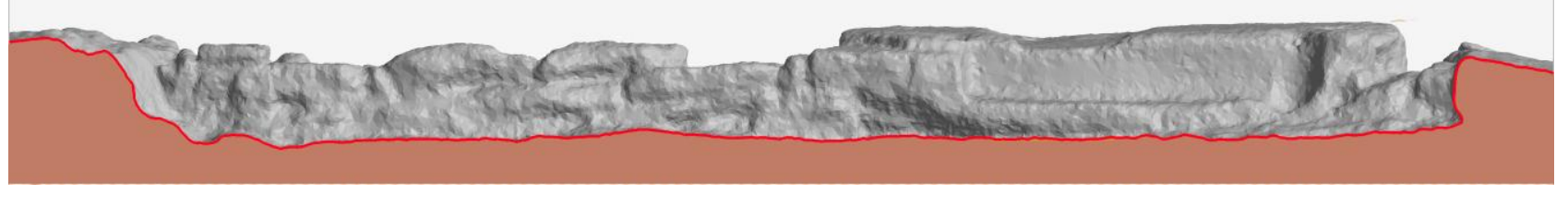

Figure 7. Cross-section of the workshop: shaded mesh

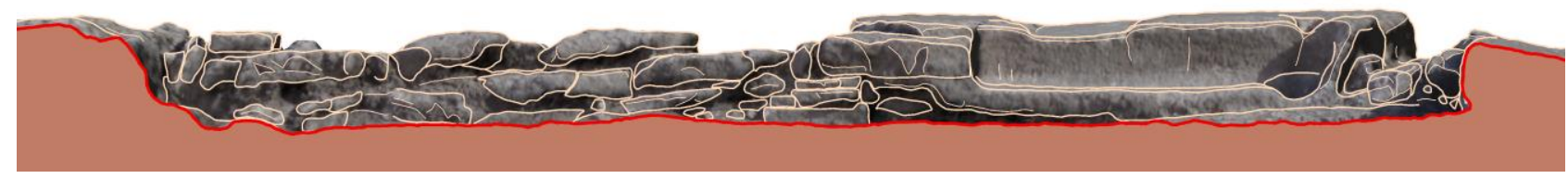

Figure 8. Cross-section of the workshop: vectorization on mesh with photographic texture 
In this case the challenge was to do a rather large 3-D model with a good level of detail. Point cloud was processed to obtain a mesh cleaned from vegetation and irrelevant parts. As the tomb is a cavity carved into the stone and very close to other tombs, the design of the replica started finding out how to cut the most significant part of the mesh to represent the tomb. The replica overall dimensions will be about $2,00 \times 1,35 \times 1,80 \mathrm{~m}(1 \mathrm{x}$ w x h).

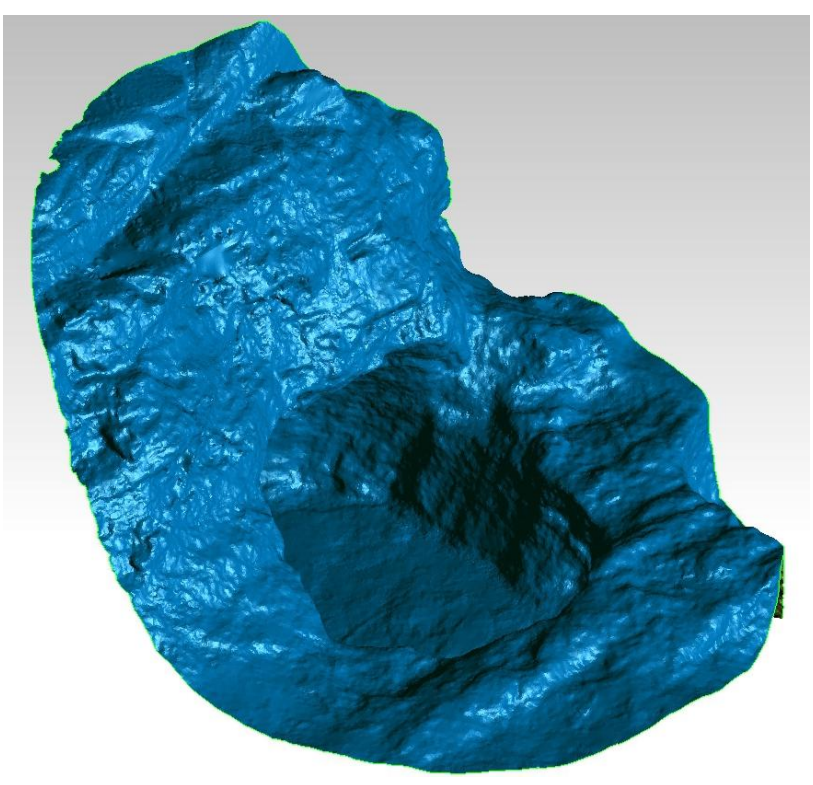

Figure 9. 3-D model of the tomb 231

As the tomb has hardly visible undercut parts, the model could be made as a thin shell mounted on a transparent support to allow a lateral vision of the whole shape of the model. As alternative, the replica could be constituted by a unique block. Depending on the selected model, it could be made by additive manufacturing (AM) techniques or by $\mathrm{CNC}$ milling of a solid block of fireproof high density polystyrene. Limassol Archaeology Museum is currently under refurbishment, so final choice will be got according with new spaces.

\section{CONCLUSIONS}

Laser scanning is more and more established as an essential survey method in archaeology, a field where traditional techniques hardly match a good metrical quality. It's still difficult to get plans and cross-sections, mostly for publication on paper, in a fully automatic way. The case study shows how it's possible to obtain almost automatically overall plans that can be compared with traditional ones, more accurate and even with more information (like shading, segmentation by elevation and so on). On the other side, detail drawings are more efficient matching point clouds or meshes with manual vectorization.

3-D modeling also allows totally new ways of representation, analysis and reproduction of archaeological sites, including replicas and virtual model as described, but also GIS-based applications and many other too.

Anyway, archaeologist's interpretation is still necessary to identify significant elements on field, as like as the collaboration between surveyors, archaeologists and computer graphic specialists to acquire in the best way all useful data for requested applications.
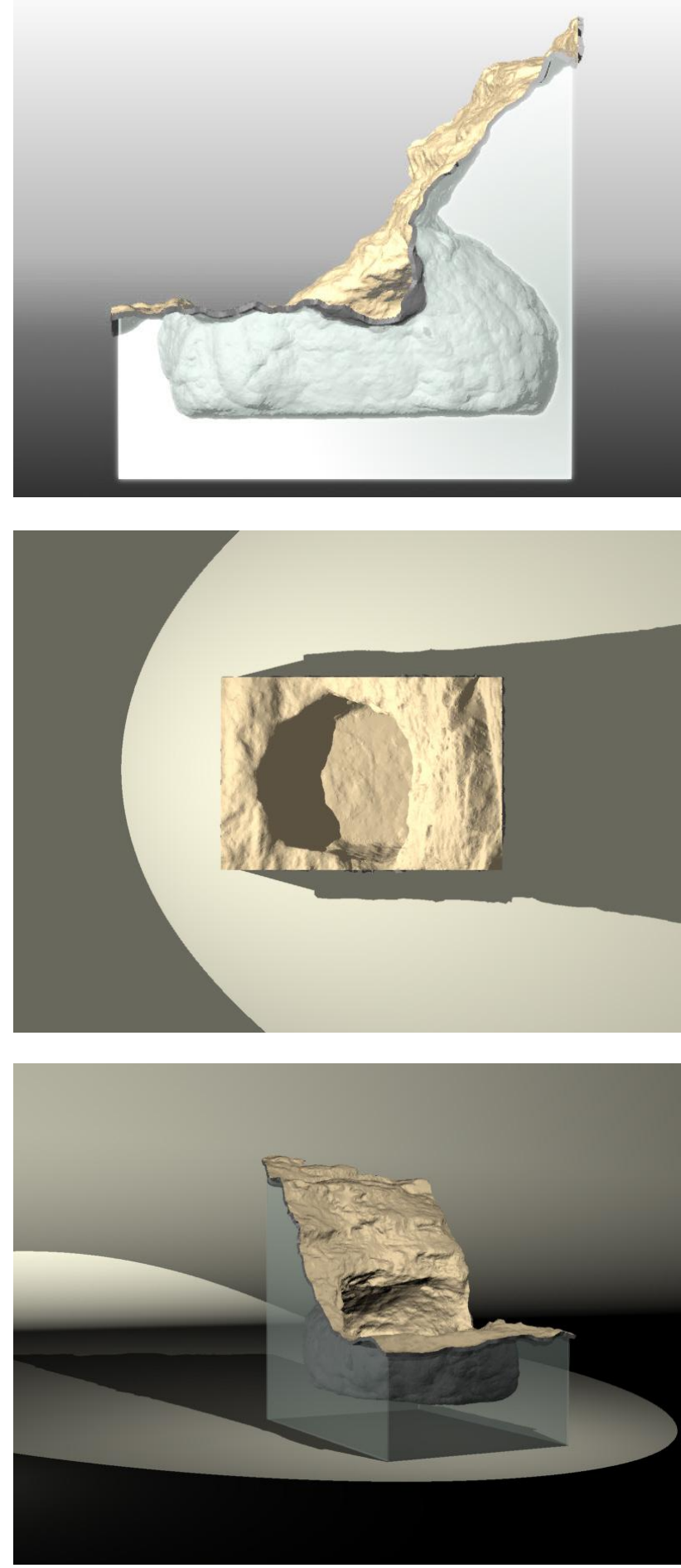

Figures 10-12. Views of the Tomb 231 replica project

\section{REFERENCES}

Adami, A., Candelato, F., Guerra, F., 2008 Verso una documentazione integrata dello scavo archeologico In: L'informatica e il metodo della stratigrafia Atti del Workshop Foggia 6-7 giugno 2008, EDIPUGLIA, Bari.

Åström, P. 1972. The Middle Cypriote Bronze Age (Swedish Cyprus Expedition IV, IB). Berlingska Boktryckeriet, Lund. 
Bombardieri, L. 2009. The MBA-LBA I period in the Kourion region: new evidences from Erimi-Laonin tou Porakou (Lemesos, Cyprus). Antiguo Oriente 7, pp. 281-300.

Bombardieri, L. 2010. Surveying the Kourion land: Field survey of the Kouris Valley and Preliminary Excavations at Erimi-Laonin tou Porakou (2007-2008 seasons). In: Researches of Cypriote History and Archaeology. Proceedings of the Conference Held in Florence, April 29-30 ${ }^{\text {th }} 2009$, edited by A.M. Jasink, and L. Bombardieri. Firenze: Firenze University Press, pp. 33-52.

Bombardieri L., Forthcoming. Detecting a sequence: Stratigraphy and Chronology of the Workshop Complex at Erimi-Laonin tou Porakou. In: Proceedings of the 9th annual meeting of Postgraduate Cypriote Archaeology (IX POCA) Held in Oxford, November 19th-21st 2009, edited by A. Georgiou. Oxford: Oxbow.

Bombardieri, L., Fossataro, D., Jasink, A.M., Menozzi, O. 2009. Preliminary Excavations at Erimi-Laonin tou Porakou (Lemesos, Cyprus). Report of the Department of Antiquities, Cyprus, pp. 131-162.

Bombardieri, L., and A.M. Jasink. 2010. The Kouris Valley Project 2007-2009: an overview. Res Antiquae 7, pp. 263-270.

Bonora, V., Spanò, A., Tucci, G. 2006. Rappresentazioni per l'archeologia, Bollettino della Società Italiana di Fotogrammetria e Topografia, n. 4/2006, pp. 25-41, ISSN 1721-971X

Bonora, V., Cruciani, G., Tucci, G., The use of 3D Scanning and Rapid Prototyping for the Documentation, Conservation and Communication of Archaeological Remains: a Recent Experience in the Sanctuary of S. M. del Lavello (Lecco, Italy), In: DMACH 2008 Conference "Digital Media and its Applications in Cultural Heritage, Amman, 3-6 novembre 2008, pp. , ISBN 9789957860257

Carpenter, J.R., 1981. Excavations at Phaneromeni, 1975-1978. In Studies in Cypriote Archaeology, edited by J. C. Biers, and D. Soren, Los Angeles, pp. 59-78.

Carra, M.L., 2010. Erimi-Laonin tou Porakou: Analisi archeobotanica dei campioni prelevati nella campagna di scavo 2009. Bologna: Privately printed.

Costantino, D., Angelini, M. G., Caprino, G., 2009 Rilievo LiDAR terrestre: Scala di Furno (Lecce). In: Atti $13^{\circ}$ Conferenza Nazionale ASITA, Bari 1-4 dicembre 2009, pp. 789794.

Flourentzos, P., 1991. Excavations in the Kouris Valley. I. The Tombs. Department of Antiquities, Nicosia.

Flourentzos, P., 2010. Contributo alla topografia di Kourion durante l'età del bronzo: una nuova proposta. In: Researches of Cypriote History and Archaeology. Proceedings of the Conference held in Florence, April 29-30th 2009, edited by A.M. Jasink, and L. Bombardieri. Firenze: Firenze University Press, pp. 9-17.

Hadjisavvas, S. 1996. Alassa: A Regional center of Alasia?". In Late Bronze Age Settlement in Cyprus: Function and Relationships, edited by P. Åström, and E. Herscher, pp. 23-38. Åström Forlag, Jonsered.
Herscher, E. 1976. South Coast Ceramic Style at the End of Middle Cypriote. Report of the Department of Antiquities, Cyprus, pp. 11-19.

Herscher, E. 1991. Beyond regionalism: toward an islandwide Middle Cypriote sequence. In Cypriot Ceramics: Reading the Prehistoric Record, edited by J.A. Barlow, D. Bolger, and B. Kling, pp. 45-50. University Museum, Philadelphia.

Iacovou, M. 2007. Site Size Estimates and the Diversity Factor in Late Cypriot Settlement Histories. Bullettin of the American Schools of Oriental Research 348, pp. 1-23.

Iacovou, M. 2008. The Palaepaphos Urban Landscape Project 2006-2007. Report of the Department of Antiquities, Cyprus 2008, pp. 263-289.

Jiménez Hernández A, López Sánchez J. M., Rodríguez Temiño, I., 2010 Sistema de información del Conjunto Arqueológico de Carmona. Sevilla. España. Virtual Archaeology Review Vol.1 n. 2 pp.102-106 ISSN 1989-9947 http://www.arqueologiavirtual.com/var/num2.swf (accessed 06/02/2011)

Laurenza, S., Putzolu, C. 2008 Dalla terra al monitor: riflessioni e considerazioni sulla gestione digitale dello scavo archeologico. In: L'informatica e il metodo della stratigrafia Atti del Workshop Foggia 6-7 giugno 2008, EDIPUGLIA, Bari.

Marchetti N., Thuesen, I., (eds.) 2008 ARCHAIA: Case Studies on Research, Planning, Characterisation, Conservation and Management of Archaeological Sites., British Archaeological Reports, Oxford.

M. Medri. Manuale di rilievo archeologico. Laterza, RomaBari, 2003.

Menozzi, O., D. Fossataro, and S. Torello di Nino. 2010. Kouris Valley Project: metodologie, finalità e primi risultati. In: Researches of Cypriote History and Archaeology. Proceedings of the Conference held in Florence, April 29-30th 2009, edited by A.M. Jasink, and L. Bombardieri. Firenze: Firenze University Press, pp. 103-119.

Remondino, F., Girardi, F., Gonzo, L., Nicolis, F., 2008 Detailed 3D reconstruction of the great inscription of Gortyna, Crete: acquisition, registration, and visualization of multiresolution data. In: Proc. of 14th Int. Conference on Virtual Systems and MultiMedia (VSMM 2008), pp. 404-412, Limassol, Cyprus

Sibilano, M. G., 2008 Documentare lo scavo archeologico: nuove forme di comunicazione del metodo stratigrafico In: L'informatica e il metodo della stratigrafia Atti del Workshop Foggia 6-7 giugno 2008, EDIPUGLIA, Bari.

Swiny, S. 1981. Bronze Age settlement patterns in south-west Cyprus. Levant 13, pp. 51-87.

Swiny, S. 2004. The role of intuitive and small scale surveys in landscape archaeology, in Archaeological Field Survey in Cyprus. Past, History, Future potentials. Proceedings of a Conference held by the Archaeological Research Unit of the University of Cyprus, 1-2 December 2000 (BSA Studies 11), edited by M. Iacovou, pp. 55-62. British School at Athens, Athens. 
Swiny, S. \& Mavromatis, C., 2000. Land behind Kourion: results of the 1997 Sotira Archaeological Project survey. Report of the Department of Antiquities, Cyprus, pp. 433-452.

Tucci, G., et al., 2010 Musealizzazione virtuale. Esperienze di rilievo e modellazione 3D per un museo interattivo e accessibile via web, Archeomatica, anno $1 \mathrm{n}^{\circ} 2$, pp.30-33.

Walberg, G., 2001-2009. The University of Cincinnati Excavations at Episkopi-Bamboula. http://www.uc.edu/news

Yamaguchi, Y., Takeniko, M., 2010 .Experimental practice using 3D scanning for understanding the structure of a stone chamber from the Kofun period, Japan - A case study of the Shobuzako Kofun, Okayama prefecture. Virtual Archaeology $\begin{array}{llllll}\text { Review Vol.1 } & \text { n.2 } & \text { pp.37-40 ISSN } & \text { 1989-9947 }\end{array}$ http://www.arqueologiavirtual.com/var/num2.swf (accessed $06 / 02 / 2011)$ 